\title{
Subclinical hypothyroidism as a cause of leg swelling in patients attending tertiary level hospital in Kathmandu
}

\author{
Prabin Adhikari ${ }^{1}, \mathrm{UN}$ Pathak $^{1}$
}

${ }^{1}$ Department of Internal Medicine, Nepal Medical College Teaching Hospital, Kathmandu, Nepal

\author{
Keywords: \\ BMI; \\ Edema; \\ peripheral edema; \\ Subclinical \\ hypothyroidism
}

\begin{abstract}
Background: Peripheral edema is one of the common causes of visit to medical outpatient department. After history taking and investigations few patients are left without diagnosis. This study was designed to find if there is any association between pedal edema and subclinical hypothyroidism when there is no other systemic disease is found.
\end{abstract}

Materials and Methods: This is a cross-sectional observational hospital based study done in one of Medical colleges in Kathmandu for a period of 2 years .All patient coming to medical OPD for the first time with bilateral painless limb swelling were evaluated data were tabulated and analyzed using Ms Excel.

Results: Out of 300 patients, 146 patients were exclude from history and clinical evaluation, 154 patients underwent laboratory evaluation. After investigations 46 patients were left without any other systemic disease. Out of them only 3 were male. About $40 \%$ of them are overweight or obese. $57 \%$ of them had high TSH level, which was significantly associated with limb swelling $(\mathrm{t}=0.012)$

Conclusion: Subclinical hypothyroidism is significantly associated with painless bilateral limb swelling when there is no other systemic cause. It is logical to investigate a limb swelling with thyroid function test however there needs to be a larger interventional study to exactly point out the cause in these patients.

\section{Correspondence:}

Dr. Prabin Adhikari, MD

Assistant Professor, Department of Internal Medicine

Nepal Medical College Teaching Hospital

ORCID ID: 0000-0002-0024-1352

Email:prabinadhikari@yahoo.com

Reveived : June $2^{\text {nd }} 2018$; Accepted : July 25 ${ }^{\text {th }}$ 2018; Published : September $1^{\text {st }} 2018$

Citation: Adhikari P, Pathak UN. Subclinical hypothyroidism as a cause of leg swelling in patients attending tertiary level hospital in Kathmandu. J Pathol Nep 2018;8:1365-8. DOI: 10.3126/ jpn.v\%vi\%i.20875

Copyright: This is an open-access article distributed under the terms of the Creative Commons Attribution 4.0 International License, which permits unrestricted use, distribution, and reproduction in any medium, provided the original author and source are credited.

\section{INTRODUCTION}

Edema is an accumulation of fluid in the intercellular tissue that results from an abnormal expansion in interstitial fluid volume. The fluid between the interstitial and intravascular spaces is regulated by the capillary hydrostatic pressure gradient and the oncotic pressure gradient across the capillary. The accumulation of fluid occurs when local or systemic conditions disrupt this equilibrium leading to increased capillary hydrostatic pressure, increased plasma volume, decreased plasma oncotic pressure (hypoalbuminemia), increased capillary permeability, or lymphatic obstruction. ${ }^{1}$ Common causes of limb swellings are liver and cardiac in-sufficiency, mal-absorption of nutrients, protein and 


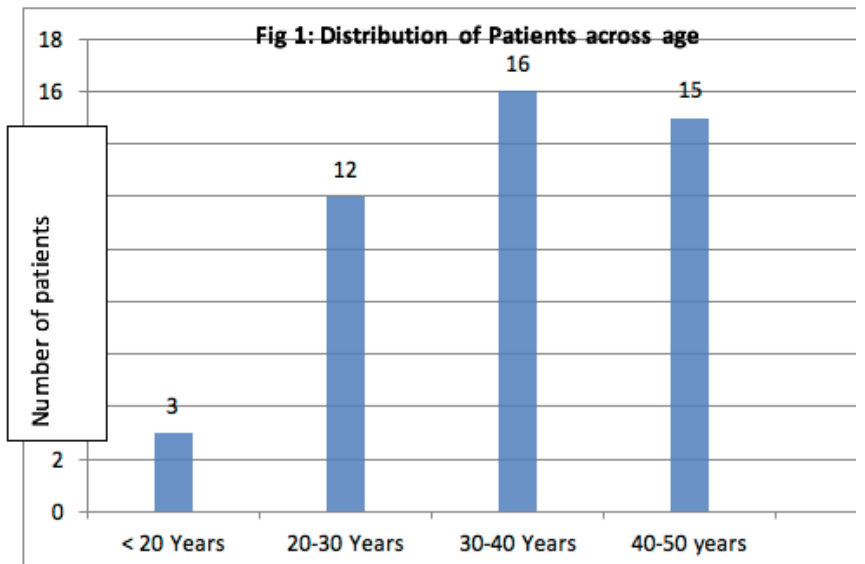

calorie deficiency, venous and lymphatic incompetence and renal disease. One of the endocrinal causes of edema is hypothyroidism. ${ }^{2}$ Swelling of limbs in hypothyroidisms is mainly due to deposition of substances Hyaluronic acid (HA) is a non-sulfated glycosaminoglycan that is present throughout the body metabolism of which is affected by thyroid hormone mainly circulating T3 level. ${ }^{3}$ Apart from this the swelling may be contributed by low body temperature as seen in Wilsons temperature syndrome with low circulating thyroid hormone which is very rarely reported in medical literature.

Although there are list of medical conditions causing bilateral limb swelling during medical work up it is difficult to label a diagnosis in few patients. ${ }^{4}$ Thyroid dysfunction is mentioned as a cause of edema, however there has not been any large scale study implicating pedal edema with thyroid failure. Few articles reports that patients with mild thyroid failure, and even subjects with high normal serum TSH values, have evidence of endothelial dysfunction, manifested by impaired flow-mediated, endothelialdependent vasodilatation which may result in limb swelling. 4,5

This study aims at finding out the incidence of subclinical hypothyroidism in patients presenting as pedal edema after ruling out cardiac disease, hepatic dysfunction, renal abnormalities and protein energy mal-absorption.

\section{MATERIALS AND METHODS}

This is a cross-sectional observational hospital based study done in patients who visited Medical OPD Nepal Medical College Teaching Hospital for painless pedal edema. Study period was 2 years, from May 2014 to April 2016. A total of 300 patients presented with symptoms of limb swelling. In various steps of history, clinical evaluation and laboratory testing, if they are found to have non-thyroidal illness contributing to the swelling, they are excluded. A total of 154 patients had thyroid function test along with other tests. Further 108 patients found to have investigations results could be attributable to the limb swelling are further

\begin{tabular}{lc} 
Table 1: BMI and Pedal edema \\
\hline Mean BMI & $23.77 \mathrm{~kg} / \mathrm{M} 2$ \\
\hline SD of BMI & $4.32 \mathrm{Kg} / \mathrm{M} 2$ \\
Asian BMI cut off for High BMI & $22.9 \mathrm{~kg} / \mathrm{m} 2$ \\
$\mathbf{Z}$ value for high BMI(critical value) & $1(0.84)$
\end{tabular}

Table 2: T3 and T4 level

\begin{tabular}{lcc}
\hline & Mean level & SD of Hormone level \\
\hline T3 & $0.98 \mathrm{ng} / \mathrm{ml}$ & 1.47 \\
T4 & $6.8 \mu \mathrm{gm} / \mathrm{dl}$ & 1.47
\end{tabular}

Table 3: TSH level in the study population

\begin{tabular}{lcc}
\hline TSH Level & Number of Patient & \begin{tabular}{c} 
Inference \\
\hline$<0.64 \mathrm{mU} / \mathrm{L}$
\end{tabular} \\
\hline $0.64-4.5 \mathrm{mU} / \mathrm{L}$ & 18 & $\begin{array}{c}\text { Subclinical } \\
\text { hyperthyroid }\end{array}$ \\
$4.5-10 \mathrm{mU} / \mathrm{L}$ & 19 & $\begin{array}{c}\text { Normal } \\
\text { Mild Subclinical } \\
\text { hypothyroidism }\end{array}$ \\
$>10 \mathrm{mU} / \mathrm{L}$ & 7 & $\begin{array}{c}\text { Severe Subclinical } \\
\text { hypothyroidism }\end{array}$
\end{tabular}

excluded leading only to 46 patients.

Eighty two patients, who were taking medications for hypertension, kidney disease and liver disease were excluded. Out of them, history of hypertension was present in 60, Kidney disease in 10 and Liver disease was present on 12 patients. They were evaluated appropriately. Further 26 patients who were giving history of ayurvedic medications were also excluded from history step only. Likewise, further 36 patients were not included as 26 of them had hypertension, 4 had irregular pulse and 6 had predominantly unilateral edema on clinical evaluation. They were evaluated depending on clinical indications. Remaining 154 patient were investigated by laboratory and imaging study. They had complete blood count, renal function test, liver function test, ECG, Chest x-ray, Echocardiography and thyroid function test. Total T3, T4 and TSH was done. Patients having abnormal Liver Function Test including low albumin were 33, those having abnormal renal function test including urine routine showing even trace albumin were 25 , they were appropriately evaluated and not included in this study. Clinical hypo or hyperthyroidism was detected in 2cases, 1 hypo 1 hyperthyroidism. Chest x-ray was abnormal in 28 cases and Echocardiography was abnormal in 20 patients. These 48 patients were further excluded from the study. Finally 46 cases that had all other systemic disease excluded were included in study. After taking consent their age, sex , height, weight were taken and Body Mass Index(BMI) were calculated Thyroid Stimulating Hormone (TSH)measurements were noted. TSH were measured in the hospital laboratory by Chemiluminescence Immunoassay (CLIA) and cut off value is taken as given in laboratory 


\begin{tabular}{lc} 
Table 4: Subclinical hypothyroid and Pedal edema \\
\hline Mean TSH & $8.84 \mathrm{mU} / \mathrm{L}$ \\
\hline SD of TSH & $14.39 \mathrm{mU} / \mathrm{L}$ \\
\hline Cut of value of Subclinical hypothyroidism & $4.5 \mathrm{mU} / \mathrm{L}$ \\
\hline Student T test for subclinical hypothyroidism & $\mathbf{0 . 0 1 2}$
\end{tabular}

reference range. Conditions were classified according to TSH value - subclinical hyperthyroid (T3,T4,TSH< $0.64 \mathrm{mU} / \mathrm{L}$ ), Normal (NormalT3,T4 and TSH), mild subclinical hypothyroidism(T3,T4,TSH $4.5-10 \mathrm{mU} / \mathrm{L})$ and severe subclinical hyperthyroidism(T3,T4, TSH $>10 \mathrm{mU} / \mathrm{L}$ ). Data were entered in Microsoft Excel sheet and analyzed.

\section{RESULTS}

Forty-six patients were analyzed out of 300 patients presenting as painless limb swelling .Out of total 46 cases 3 were male and 43 were female. Mean age of presentation was 33.86 years (SD 8.12). Thirty-one patients presented in between $30-50$ years of age (fig.1).

Mean height of the patient was 1.51 meters (SD 0.14) Mean weight of the patient was 54.69 Kilograms (SD -12.52) and mean Body Mass Index(BMI) was $23.77 \mathrm{~kg} / \mathrm{m} 2$ (SD- 4.32). Out of 46 patient 18 patient were either overweight or obese. However high BMI is not significantly associated with swelling $(Z$ test $=1)$. Total T3 and T4 were measured level of which was shown in table 2. By definition of Subclinical hypothyroidism their level was within the normal range.

TSH level of the patients are shown in the table 3 . Mean TSH was $8.84 \mathrm{mU} / \mathrm{L}(\mathrm{SD}$ 14.39). Mild and severe subclinical hypothyroidisms were significantly associated with swelling of these groups of patients. (Student $t$ test $=$ 0.012). Table 4

\section{DISCUSSION}

Subclinical hypothyroidism is biochemically defined as an elevated serum thyrotropin level in combination with a serum free T4 level that is within the population reference. ${ }^{6}$ Prevalence of abnormal thyroid function continues to be debated. Numerous studies from various countries differ in their prevalence estimates for both hypothyroidism and hyperthyroidism. In perhaps the best longitudinal study conducted to date, Tunbridge et $\mathrm{al}^{7}$ found that $7.5 \%$ of women and $2.8 \%$ of men of all ages in Whickham, England, had serum thyrotropin (TSH) levels greater than $6 \mathrm{mIU} / \mathrm{L}$. After reviewing 12 such studies across many different cultures, Vanderpump and Tunbridge concluded that primary thyroid gland failure (TSH $>6 \mathrm{mIU} / \mathrm{L}$ ) occurs in $5 \%$ of multiple populations. ${ }^{8}$ There is no large scale prevalence data available in Nepal. However a hospital based study of eastern Nepal shows about $20 \%$ of their patient sent for laboratory evaluation had subclinical hypothyroidisms(TSH
$>6.2 \mathrm{mIU} / \mathrm{L})^{9}$ In our study out of 46 patient, $57 \%$ were having high TSH which higher than the study done in eastern Nepal and probably points towards etiology of the swelling.

There are numerous direct and indirect biochemical responses to hypothyroidism that affect nearly all organ systems. At the capillary level, there is increased permeability resulting in the accumulation of proteins and mucopolysaccharides in the interstitium, followed by sodium and water. There is a concomitant expansion in total body water and sodium. ${ }^{10}$ Although there are few case repots of subclinical hypothyroidism causing edema, there has not been any study looking specifically subclinical hypothyroidism as a cause of pedal edema. Increased rates of fatigue, muscle weakness, weight gain, cold intolerance, and constipation have also been reported variably in association with subclinical hypothyroidism. ${ }^{11}$ There has been description of patients presenting with swelling and accumulation of fluid in serous cavities with subclinical hypothyroidism. Parving et al demonstrated that combination of increased extravasations of plasma protein and lack of compensatory lymph flow and protein return rate swelling and fluid collection in serous cavity. ${ }^{12}$ It has been reported that development of pleural effusion depends on duration of hypothyroidism than degree of hypothyroidism ${ }^{13}$ Furthermore tissue hypothyroidism at peripheral target organ may be different for different individual, there have been reports that people having severe biochemical derangement had only mild signs while those having mild derangement had severe signs and symptoms. ${ }^{14}$

Subclinical hypothyroidism is mainly found in female. In a study done in Pakistan shows only $6.2 \%$ of the people presenting with subclinical hypothyroidism were male. ${ }^{15}$ This is in par with our study where out of 46 patients only 3 are male. Most common age of presentation in our study is $30-50$ years of age. This is similar to a study done in Uzbekistan which shows prevalence of $64 \%$ age more than 40 year of age. ${ }^{16}$

High TSH level for the test ha also to be viewed in context variability of TSH in various age, sex, ethnicity and body mass index. A study done in more than 4000 Delhi adults shows that mean TSH value was $2.2 \pm 0.9 \mathrm{mIU} / \mathrm{L} .{ }^{17} \mathrm{In}$ another study done in India shows that TSH with increasing BMI. As the BMI increased, mean TSH in the BMI range also increased. The individuals with higher BMI had higher TSH and this trend continued from underweight to Obese. The mean TSH of underweight group was $1.6036 \mathrm{mIU} / \mathrm{L}$, normal weight group $2.1727 \mathrm{mIU} / \mathrm{L}$, overweight group $2.2870 \mathrm{mIU} / \mathrm{L}$ and obese group $2.6416 \mathrm{mIU} / \mathrm{L} .{ }^{18} \mathrm{In}$ our study $18(40 \%)$ of the people were either obese or overweight but mean TSH value is almost four times the level of TSH in obese people in Indian study. So it is unlikely that only obesity is contributing to the high TSH in this study. Severe Subclinical hypothyroidism were observed in 7 (15\%) of 
the patient.

\section{CONCLUSION}

In this observational study done in a medical college, patients with painless pedal edema were found to have higher BMI and high TSH value. TSH value was significantly co-related with swelling. It is logical to ask for thyroid function test to evaluate bilateral painless limb swelling; however there need to be more data on such cases and interventional trials to show that people with high TSH benefit from thyroxine therapy.

\section{Conflict of interest: None}

\section{REFERENCES}

1. Cho S, Atwood JE. Peripheral edema. Am J Med. 2002;113:580-6. DOI: $\underline{\text { Crossref }}$

2. Yale SH, Mazza JJ. Approach to diagnosing lower extremity edema. Compr Ther. 2001;27:242-52.DOI: $\underline{\text { Crossref }}$

3. Stern R.Hyaluronan catabolism: a new metabolic pathway. Eur J Cell Biol.2004;83: 317-325.DOI: Crossref

4. Lekakis J, Papamichael C, Alevizaki M, P, et al. Flowmediated, endothelium-dependent vasodilatation is impaired in subjects with hypothyroidism, borderline hypothyroidism, and high-normal serum thyrotropin (TSH) values.Thyroid 1997:7:411-4 . DOI: $\underline{\text { Crossref }}$

5. Surks MI, Ortiz E, Daniels GH, et al. Subclinical thyroid disease: scientific review and guidelines for diagnosis and management. JAMA. 2004;291:228-38. DOI : $\underline{\text { Crossref }}$

6. Peeters RP. Subclinical Hypothyroidism.N Engl J Med 2017;376:2556-65. DOI: Crossref

7. Tunbridge WM, Evered DC, Hall R, et al. The spectrum of thyroid disease in a community: the Whickham survey. Clin Endocrinol (Oxf). 1977;7:481-93. DOI: $\underline{\text { Crossref }}$

8. Vanderpump MP, Tunbridge WM, French JM, et al. The incidence of thyroid disorders in the community: a twentyyear follow-up of the Whickham Survey.Clin Endocrinol (Oxf). 1995;43:55-68. DOI: Crossref

9. Rohil V, Mishra AK, Shrewastwa MK,Mehata KD, Lamsal M, Baral N, et al. Subclinical hypothyroidism in eastern Nepal: A hospital based study. Kathmandu Univ Med J 2010:30:231-7. DOI: $\underline{\text { Crossref }}$
10. Hierholzer K, Finke R.Myxedema. Kidney Int. 1997;51: S82-9. Crossref

11. Jorde R, Waterloo K, Storhaug H, Nyrnes A, Sundsfjord J, Jenssen TG.. Neuropsychological function and symptoms in subjects with subclinical hypothyroidism and the effect of thyroxine treatment. J Clin Endocrinol Metab 2006;91:145-3. DOI: $\underline{\text { Crossref }}$

12. Parving HH, Hansen JN, Nielsen SL, Rossingn N, Munk O, Lassen NA . Mechanism of edema formation in myxoedema and relatively slow lymphatic drainage. N Engl J Med. 1979;301:460-5. DOI: Crossref

13. Gottehrer A, Roa J, Standford GC, Chernow B, Sahn SA. Hypothyroidism and pleural effusion Chest 1990;98:1130-2. DOI: Crossref

14. Zulewski H, Muller B Exer P, Miserez AR, Staub JJ. Estimation tissue hypoghytoidism by a new clinical score: evaluation of patient with various grades of hypothyroidism and control. J Clin Endocrinol Metab 1997:82:771-6. DOI: Crossref

15. Khan MA, Ahsan T, Rehman UL, Jabeen R, Farouq S. Subclinical Hypothyroidism: Frequency, clinical presentations and treatment indications. Pak J Med Sci. 2017;33:818-22.DOI Crossref

16. Ismailov $\mathrm{S}$, Dilbar A. Prevalence of subclinical hypothyrodidism among female residents of Anduan region in Uzbekistan. Medical and Health Science Journal 2014;15:6973. DOI: $\underline{\text { Crossref }}$

17. Marwaha RK, Tandon N, Ganie MA,Mehan A, Shastry A, Garg MK et al. Reference range of thyroid function (FT3, FT4 and TSH) among Indian adults.Clin Biochem. 2013;46:3415. DOI Crossref

18. Solanki A.Shaifali B, Sushil J, Vivek S,Sukla AS.Relationship of serum thyroid stimulating hormone with body mass index in healthy adults.Indian J Endocrinol Metab. 2013;17:S167S9. DOI: $\underline{\text { Crossref }}$ 